\title{
Ecophysiological Characterization of Seven Cultivars of Maize (Zea mays $L$.), in the Valley of Tehuacan
}

\section{Alejandro Morales-Ruíz ${ }^{1}$, Ernesto Díaz-López ${ }^{1}$, Edgar Josanine Vargas-Ramírez ${ }^{1}$, Rodolfo Clemente-Resendíz-Melgar ${ }^{3}$, Erika Teresa Díaz-Oreján ${ }^{2}$ and Aurelio Trujillo Álvarez ${ }^{4}$}

${ }^{1}$ Ingeniería en Agricultura Sustentable y Protegida, Universidad Tecnológica de Tehuacán, Prolongación de la 1 sur, 1101 San Pablo Tepetzingo Tehuacán, Puebla. C. P. 75859.

${ }^{2}$ Ingenieria en procesos alimentarios Universidad Tecnológica de Tehuacán, Prolongación de la 1

sur, 1101 San Pablo Tepetzingo Tehuacán, Puebla. C. P. 75859,

${ }^{3}$ Centro de Bachillerato Tecnológico Agropecuario No. 76. Km 115 Carretera México-

Telixtlahuaca, Santamaría Tecomavaca, Teotitlán de Flores Magón, Oaxaca. C.P. 68590.

${ }^{4}$ Estudiante becario PRODEP, Ingeniería en Agricultura Sustentable y Protegida. Universidad

Tecnológica de Tehuacán, Prolongación de la 1 sur, 1101 San Pablo Tepetzingo Tehuacán,

Puebla. C. P. 75859.

*Corresponding author

\section{A B S T R A C T}

\section{Keywords}

Index of leaf area,

Yield,

Nitrogen,

Maize free

pollination

Article Info

Accepted:

20 January 2017

Available Online:

10 February 2017
The primary objective of this research was to evaluate the performance of seven maize genotypes function to five levels of nitrogen, in the spring-summer cycle 2014, for evaluating: leaf area index, biomass, yield and harvest index under a design randomized complete block factorial arrangement, low irrigation conditions on the premises Universidad Tecnologica de Tehuacán in Tehuacán Puebla México which is located at $18^{\circ}$ 24'51" north latitude, $97^{\circ} 20^{\prime} 00^{\prime \prime}$ west longitude and 1409 meters above sea levela climate $\mathrm{Bs}_{1}\left(\mathrm{w}^{\prime}\right) \mathrm{eg}$, corresponds to a dry climate with annual mean temperature over $18^{\circ} \mathrm{C}$ and less than $27^{\circ} \mathrm{C}$, precipitation higher than $400 \mathrm{~mm}$ and smaller than $600 \mathrm{~mm}$ rain fall stations. Results indicate that the level of $180 \mathrm{kgha}^{-1}$ of $\mathrm{N}$, It presents the maximum values of IAF, biomass and yield, whereas the cultivating Tehuacán, it reached maximum production of biomass and yield, nitrogen $x$ cultivar interaction indicated that the implementationof $180 \mathrm{kgNha}^{-1}$ in the cultivar Altepexi. Sample the maximum grain yield and this geno type that best suits to the environmental conditions in the study area.

\section{Introduction}

Maize (Zea mays L.) is considered as a basic crop for Latin American towns, Due to the multiple uses of which it is object within these one can cite: Preparation of tortilla, forage, extraction of syrup of high fructose, extraction of starch(Segovia y Alfaro, 2009;
Robutti, 2004) and for the synthesis of biofuels such as bioethanol $\mathrm{E}_{5}$ and $\mathrm{E}_{10}$ (Alvarez, 2009). This crop was domesticated by the ancient cultures that inhabited the valley of Tehuacán-Cuicatlan, as the studies of Richard McNeish in the sixties have shown 
(Mc Neish, 1964), who excavating in the cave of the corn in Coxcatlán, Puebla, were able to recover maize germplasm, which when dated by the technique of ${ }^{14} \mathrm{C}$, managed to locate it in the year 8000 b.c, making it evident that this area was domesticated (Carillo, 2009).The valley of Tehuacán-Cuicatlán, is between the neighboring states of Puebla and Oaxaca and has an extension of 490,186 hectares, the predominant climate is $\mathrm{Bs}_{1}$ type with dominance of xerophyte scrub (Secretaria de Medio Ambientey Recursos Naturales, 2013).The ecophysiological characterization, this is a technique used to determine the qualities of a genotype to adapt to the environment of a region, due to genotype $\mathrm{x}$ environment interaction.

Because maize is a crop that presents a wide adaptability to the different climates and regions where it is planted, it is necessary to perform this characterization for the different materials, and to establish the proper agronomic management for the crop (Gordon, 2006; Perez, 2000).In this regard, Rocandio et al., (2014), mention that to understand the breadth of environmental adaptability of the maize crop, it is necessary to evaluate the morphological characters of these materials and classify them into populations to determine their uses.

On the other hand, Navarro et al., (2012), indicate that it is important to characterize the creole materials of the coast of the state of Guerrero, due to its cultural, economic and adaptability to the ecological conditions of the area. Therefore, the main objective of this study was: to characterize seven maize cultivars in the Tehuacán Valley in response to nitrogen fertilization. The hypothesis was: nitrogen fertilization in combination with environmental factors will affect maize crop growth and yield in the Tehuacán Valley, Puebla.

\section{Materials and Methods}

The present study was carried out in San Pablo Tepetzingo Tehuacán, Puebla at $18^{\circ}$ $24 ' 51$ " north latitude, 97 $20^{\prime} 00$ " longitude west and 1409 meters of altitude. Under a climate $\mathrm{Bs}_{1}(\mathrm{w}$ ') eg, which corresponds to a dry climate, with annual average temperature higher than $18^{\circ} \mathrm{C}$ and lower than $27^{\circ} \mathrm{C}$,Precipitation greater than $400 \mathrm{~mm}$ and less than $600 \mathrm{~mm}$ with rainy season from May to September, presence of intraestival drought, temperature fluctuation between the warmest and coldest month greater than $7^{\circ} \mathrm{C}$ and lower than $14^{\circ} \mathrm{C}$ and the warmest month occurs before the summer solstice, which occurs in April (Garcia, 2005). The germplasm consisted of seven cultivars of maize, five of free pollination: San Bartolo, San Antonio Cañada, Tehuacán, Cuayucatepec and Altepexi and two hybrids: $\mathrm{H}-\mathrm{Cimarron}$ and H-7573, which were planted during the month of April 2013, in a vertisol soil with a pH of 7.9 and a C.E, $4.5 \mathrm{dS} \mathrm{m}^{-1}$ at $25^{\circ} \mathrm{C}$, an initial nitrogen level of $5.4 \mathrm{mg} \mathrm{kg}^{-1}$ and $2.5 \%$ organic matter. The topological arrangement was $(0.17 \times 0.80)$ resulting in 7.3 plants $\mathrm{m}^{-2}$. The whole experiment was fertilized with $90 \mathrm{~kg} \mathrm{ha}^{-1}$ of triple calcium superphosphate $\left(46 \% \mathrm{P}_{2} \mathrm{O}_{5}\right)$ and $60 \mathrm{~kg} \mathrm{ha}^{-1}$ of potassium whose source was potassium chloride $\left(60 \% \mathrm{~K}_{2} \mathrm{O}\right)$. The response variables were: Index of leaf area which was determined with equation $\mathrm{LAI}=\left(\frac{(L A)(P D)}{10000}\right)$ where: LAI, is the leaf area index; LA, Leaf area, PD, population density. The leaf area, was determined by the ratio $\mathrm{LA}=(\mathrm{L})(\mathrm{A})$ (0.75), where LA, leaf area; L, sheet length and A, sheet width, (Diaz et al., 2010; Mendez, 1993); Biomass of the aerial part, subjecting the leaves to drying, stems, bracts, inflorescences in a forced air oven at $70^{\circ} \mathrm{C}$ until reaching constant weight; yield, weighing the ten-grain kernel and obtaining the corresponding average and harvest index, 
with the equation, $\mathrm{HI}=\frac{A Y}{B Y}$ where, $\mathrm{HI}$, harvest index; AY, agronomic yield; BY, biological yield (Escalante and Kohashi, 1993). The experiment was evaluated under a randomized complete block design with factorial arrangement, under the mathematical model $Y_{i j k}=\mu+A_{i}+B_{j}+(A B)_{i j}+\beta_{k}+\varepsilon_{i j k}$ where: $Y_{i j k}$, is the response variable of the $i$-th nitrogen level (Factor A) in the $\mathrm{j}$-th maize (Factor B) cultivar in the $\mathrm{k}$-th block; $\mu$, is the true overall mean; $A_{i}$, is the $i$-th level of nitrogen; $B_{j}$, is the $j$-th cultivar; $(A B)_{i j}$, is the interaction of the $\mathrm{i}$-th level of nitrogen in the $\mathrm{j}$-th maize crop; $\beta_{\mathrm{k}}$, is the effect of the k-th block and $\varepsilon_{\mathrm{ijk}}$, is the experimental error of the $i$-th level of nitrogen in the $\mathrm{j}$-th maize cultivar in the $\mathrm{k}$-th block (Cochran and Cox, 2008). The study factors were five nitrogen levels: 0, 60, 120, 180 and $240 \mathrm{~kg} \mathrm{ha}^{-1}$ of $\mathrm{N}$ and seven cultivars of maize: San Bartolo, San Antonio Cañada, Tehuacán, Cuayucatepecy Altepexi and two hybrids: H-Cimarron and $\mathrm{H}-7573$ and three replications $(5 \times 7 \times 3)=105$ experimental units. To the response variables when these were significant, Tukey's multiple comparison test was applied at a significance level of $5 \%$ of error probability.

\section{Results and Discussion}

In table 1,we present the analysis of variance for the study factors levels of nitrogen and maize cultivars, in the it can be observed that for the factor nitrogen levels, there were highly significant differences for the variables LAI, biomass and yield. For the cultivars factor, there were only highly significant differences for biomass and yield. With respect to the interaction between both study factors, the nitrogen level per cultivar turned out to be highly significant for biomass and yield. Thus, the coefficient of variability ranged from 14.6 to $27.9 \%$, indicating that the values were reliable, result of adequate data collection. The best response was achieved with the application of $180 \mathrm{~kg} \mathrm{ha}^{-1}$ of $\mathrm{N}$, yielding a yield of $1339.2 \mathrm{~g} \mathrm{~m}^{-2}$, surpassing 240, 120, 60 and $00 \mathrm{Kg} \mathrm{ha}{ }^{-1}$ of $\mathrm{N}$, in percentages ranging from 6.9, 14.2, 23.6 and $29.4 \%$, respectively. These results partially agree with what was reported by Zamudio et al., (2015), who point out that nitrogen is a macro nutrient that significantly influences yield, also report that the maximum yield was obtained with $240 \mathrm{~N}$, when evaluating five hybrids. Regarding biomass and LAI, the best level was $180 \mathrm{~N}$, with $3624.9 \mathrm{~g} \mathrm{~m}^{-2}$ and 3.78 respectively, followed by $240 \mathrm{~N}$ level with $3311.6 \mathrm{~g} \mathrm{~m}^{-2}$, and 3.33 , the lowest production of biomass and LAI, was for the control with $2373.1 \mathrm{~g} \mathrm{~m}^{-2}$, and 2.47 respectively. For the cultivars factor, Tehuacan presented the highest values for yield and biomass with 1350.2 and $3809.4 \mathrm{~g} \mathrm{~m}^{-2}$, Followed by Altepexi, San Bartolo and San Antonio Cañada with regard to hybrids, H- Cimarrón, presented the highest value with $1070.9 \mathrm{~g} \mathrm{~m}^{-2}$, Surpassing in an order of $10 \%$ to the $\mathrm{H}-$ 7573. This partially agrees, as reported by Morales et al., 2014, who evaluated free and hybrid pollination maize in Toluca Mexico, Indicate that the criollos surpassed the hybrids, indicating that the meteorological conditions affect the expression of the genotype of the hybrids.

The interaction nitrogen $\mathrm{x}$ cultivar is presented in figure 1 . In it is appreciated that the maximum production of dry biomass, was presented in the cultivars San Bartolo, HCimarron, Tehuacan and Altepexi when interacting with $180 \mathrm{~kg} \mathrm{ha}^{-1}$ of nitrogen with 3,432.66, 3,668.00, 4,867.00 and 4,422.33 g $\mathrm{m}^{-2}$, while cultivars H-7573 and San Antonio Cañada assigned high biomass values with $240 \mathrm{~kg} \mathrm{ha}^{-1}$ of $\mathrm{N}$, Cuayucatepec assigned its high values when interacting with $120 \mathrm{~kg} \mathrm{ha}^{-1}$ of N. Regarding the low values in the biomass allocation, these were presented in the witnesses for all the materials in question. 
Table.1 Analysis of variance and comparison of means for seven maize cultivars in the Tehuacan Valley, Spring-Summer, 2014 Cycle

\begin{tabular}{|c|c|c|c|c|}
\hline factor & LAI & 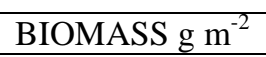 & YIELD g m $^{-2}$ & $\mathrm{HI}$ \\
\hline Levels N (A) & $* * *$ & $* * *$ & $* * *$ & $\mathrm{~ns}$ \\
\hline $00 \mathrm{~N}$ & $2.47 \mathrm{~d}$ & $2373.1 \mathrm{~d}$ & $944.9 \mathrm{~b}$ & $0.38 \mathrm{a}$ \\
\hline $60 N$ & $2.77 \mathrm{bc}$ & $2731.2 \mathrm{~cd}$ & $1023.2 \mathrm{~b}$ & $0.39 \mathrm{a}$ \\
\hline $120 N$ & $3.17 \mathrm{bc}$ & $3035.1 \mathrm{bc}$ & $1149.7 \mathrm{ab}$ & $0.37 \mathrm{a}$ \\
\hline $180 \mathrm{~N}$ & $3.78 \mathrm{a}$ & $3624.9 \mathrm{a}$ & $1339.2 \mathrm{a}$ & $0.53 \mathrm{a}$ \\
\hline $240 N$ & $3.33 \mathrm{ab}$ & $3311.6 \mathrm{ab}$ & $1247.2 \mathrm{a}$ & $0.38 \mathrm{a}$ \\
\hline DSH $_{0.5}$ & 0.557 & 380 & 223.1 & 0.29 \\
\hline Cultivar (B) & $\mathrm{ns}$ & $* * *$ & $* * *$ & $\mathrm{~ns}$ \\
\hline San Bartolo & $3.16 \mathrm{a}$ & $2885.5 \mathrm{c}$ & $1193.4 \mathrm{abc}$ & $0.37 \mathrm{a}$ \\
\hline San Antonio Cañada & $3.23 \mathrm{a}$ & $3382.1 \mathrm{ab}$ & $1173.6 \mathrm{abc}$ & $0.35 \mathrm{a}$ \\
\hline H-Cimarrón & $3.19 \mathrm{a}$ & $2288.7 \mathrm{~d}$ & $1070.9 \mathrm{abc}$ & $0.45 \mathrm{a}$ \\
\hline H-7573 & $3.22 \mathrm{a}$ & $2138.4 \mathrm{~d}$ & $966.3 \mathrm{c}$ & $0.43 \mathrm{a}$ \\
\hline Tehuacán & $2.95 \mathrm{a}$ & $3809.4 \mathrm{a}$ & $1350.2 \mathrm{a}$ & $0.37 \mathrm{a}$ \\
\hline Cuayucatepe & $3.05 \mathrm{a}$ & $3093.9 \mathrm{bc}$ & $973.7 \mathrm{bc}$ & $0.32 \mathrm{a}$ \\
\hline Altepexi & $2.93 \mathrm{a}$ & $3508.1 \mathrm{ab}$ & $1257.7 \mathrm{ab}$ & $0.56 \mathrm{a}$ \\
\hline $\mathrm{SDH}_{0.05}$ & 0.715 & 487.5 & 286.2 & 0.36 \\
\hline$A * B$ & ns & $* *$ & $* *$ & Ns \\
\hline $\mathrm{CV} \%$ & 20.8 & 14.6 & 22.6 & 27.9 \\
\hline
\end{tabular}

Fig.1 Interaction between the factors Nitrogen level x cultivar in maize (Zea mays L.), for biomass production in the valley of Tehuacan, Puebla.Spring-Summer 2014 Cycle

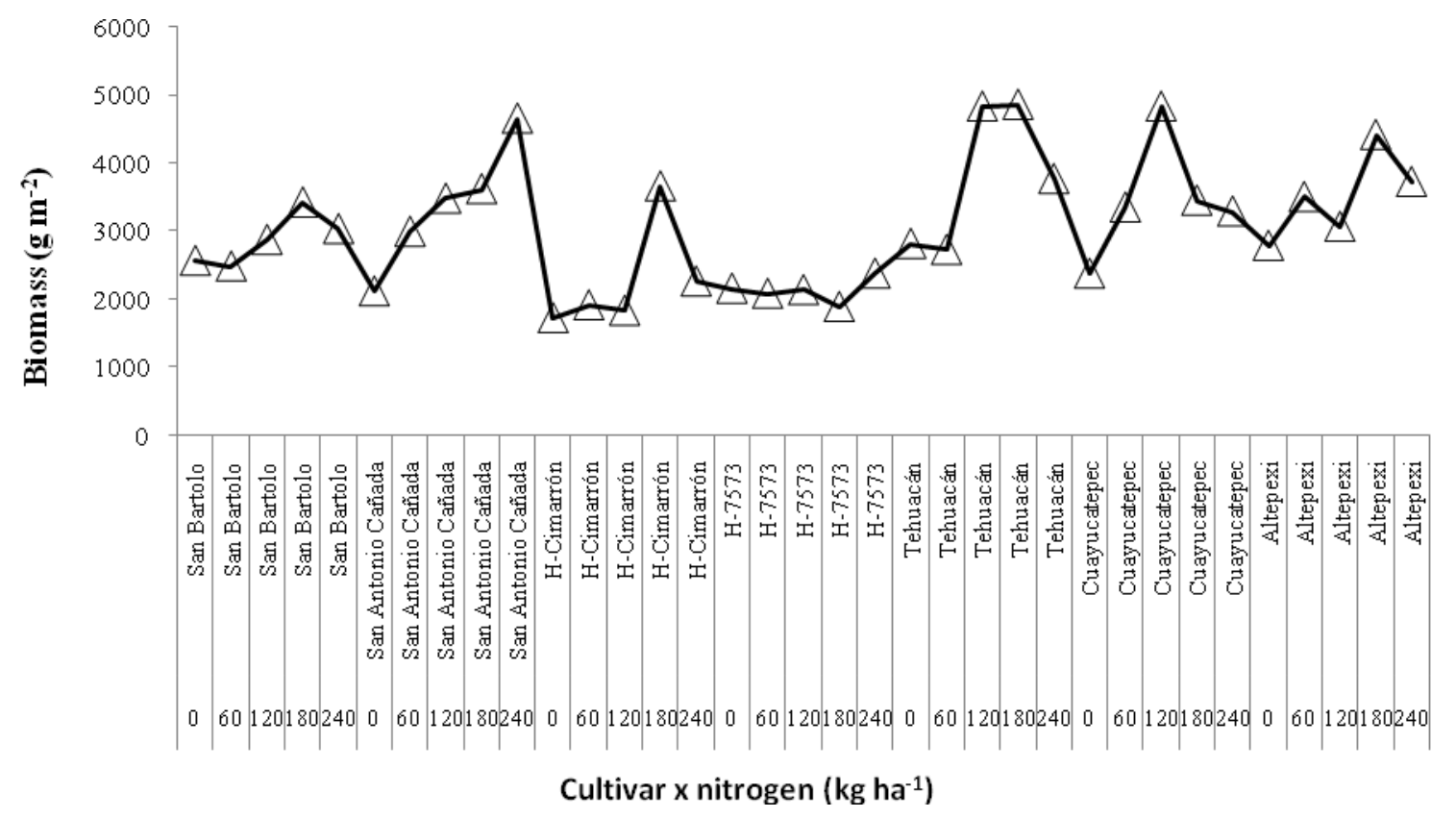


Fig. 2 Interaction among the factors Nitrogen level x cultivar in maize (Zea mays L.), for agronomic performance in the valley of Tehuacan, Puebla.Spring-Summer 2014 Cycle

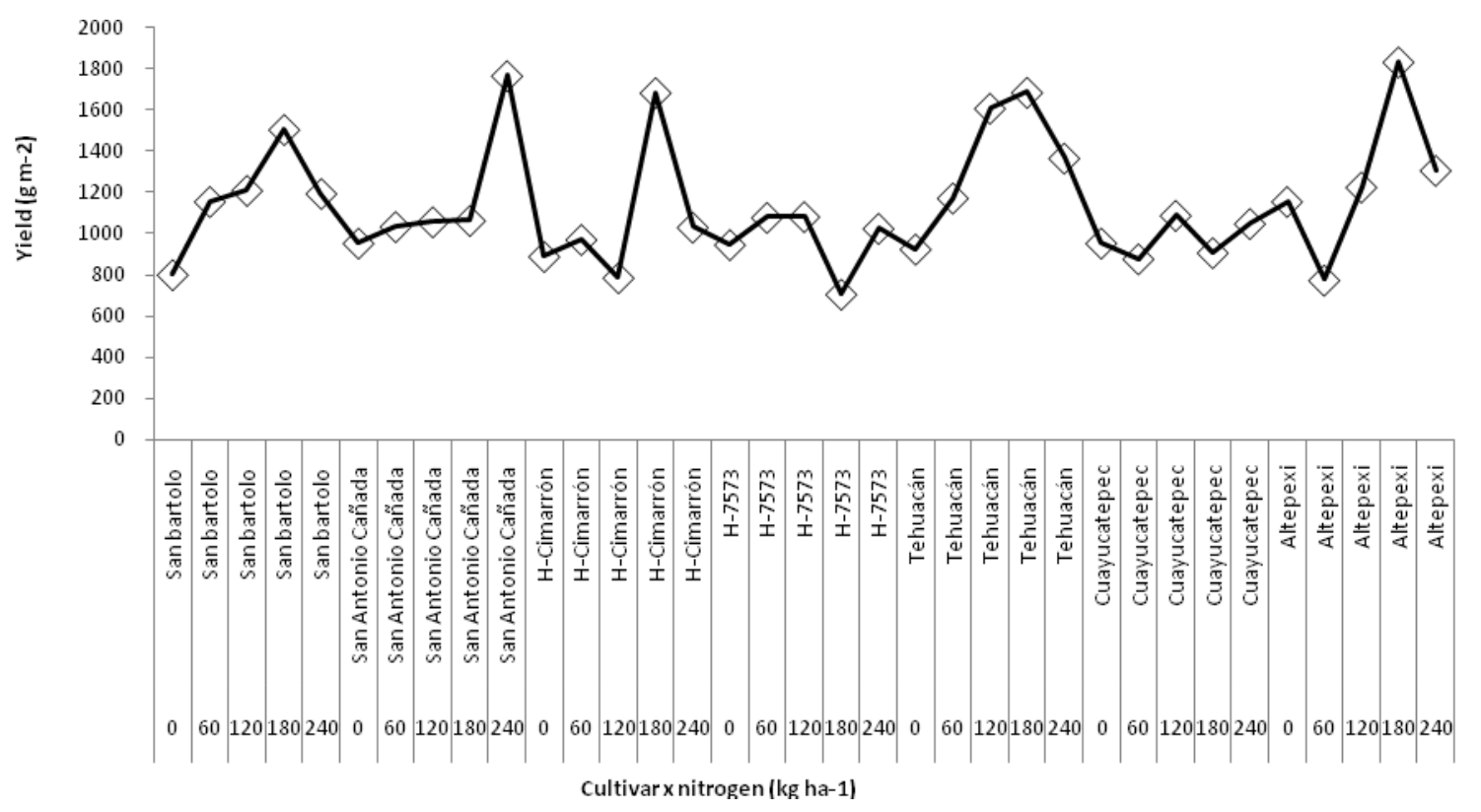

The interaction for the nitrogen $\mathrm{x}$ cultivar factors for agronomic performance is presented in figure 2. It is possible to observe that the maximum yield for the cultivars San Bartolo, Cimarron, Tehuacán and Altepexi was with a fertilization of $180 \mathrm{~kg} \mathrm{ha}^{-1}$ of $\mathrm{N}$, with $1503.86,1682.43,1684.1$ and $1831.60 \mathrm{~g}$ $\mathrm{m}^{-2}$ respectively, while the cultivars San Antonio Cañada and Cuayucatepec obtained the maximum yields with the application 240 $\mathrm{kg} \mathrm{ha}{ }^{-1}$ of $\mathrm{N}, \mathrm{H}-7573$ only reached its maximum yield with $120 \mathrm{~kg} \mathrm{ha}^{-1}$ of $\mathrm{N}$ with $1080.83 \mathrm{~g} \mathrm{~m}^{-2}$.

In this respect the cultivar Altepexi surpassed in yield to the cultivars, Tehuacán and Cimarron in $8.05 \%$, while to San Bartolo with $17.89 \%$. These results differ with those reported by Ortiz et al., (2013), who worked with the cultivar Altepexi under the conditions of San Pablo Tepetzingo Tehuacán Puebla, Report a yield of $1159.20 \mathrm{~g} \mathrm{~m}^{-2}$ with a fertilization of $180 \mathrm{~kg} \mathrm{ha}^{-1}$, Being $36.6 \%$ less than reported in the present study, these differences may be due to the different years in which the present studies were carried out, as well as to the amount of rain that occurred in those years.

From the genetic materials and nitrogen levels evaluated in the present investigation, the following conclusions were derived:

The best nitrogen dose was $180 \mathrm{~kg} \mathrm{ha}^{-1}$, producing the highest LAI, biomass and yield values. From the cultivars factor, Tehuacán presented the highest biomass and yield expression. The cultivar $\mathrm{x}$ nitrogen interaction showed that Altepexi when interacting with a level of $180 \mathrm{~kg} \mathrm{ha}^{-1}$ observed the highest yield, in addition to a better adaptability to the study area.

\section{Acknowledgments}

The author of the present investigation thanks the economic support received for the accomplishment of the present study, through the support PRODEP. In the call for support to the incorporation of new PTC 2013, to the project "F-PROMEP-38/Rev-04 SEP/23-005" Entitled: "Caracterizacióneco fisiológica de maícescriollos del valle de Tehuacán”. 


\section{References}

Alvarez, M.C. 2009. Biofuels: historical, technological development, current markets and international trade. Economía Informa. 359: 63-89.

Carrillo, T.C. 2009. The Origin of Maize Nature and Culture in Mesoamerica.Ciencias. 92(93): 4-13.

Cochran, G.W. and Cox, M. G. 2008.Experimental designs. Ed. Trillas, 661 p.

Diaz, L.E., Escalante, E.J.A., Rodríguez, G.M.T. and Gaytán, A.E.A. 2010.Production of snap bean according to the type of trellis.Revista Chapingo Serie Horticultura. 16(3): 215-221.

Escalante, E.J.A. and Kohashi, S.J. 1993.The yield and growth of bean.Manual for taking data. Centro de Botánica-Colegio de Postgraduados. Montecillo, México. 84 p.

Espinosa, C.A., Tadeo, R.M., Turrent, F.A., Gómez, M.N., Sierra, M.M., Palafox, C.A., Caballero, H.F., Valdivia, B.R. and Rodríguez, M.F. 2008.Thepotential of native and improved maize varieties. Ciencias 9293:118-125.

García, E. 2005. Modifications to the climate classification system of Köppen, to adapt it to the conditions of the Mexican Republic.Instituto de Geografía. UNAM.

Gordón, M.R., Camargo, B.I., Franco, B.J., González, S.A. 2006. Evaluation of the adaptability and stability of 14 hybrids of maize, azuero, panama. Agronomía Mesoamericana. 17(2): 189-199.

MacNeish, S.R. 1964. Ancient mesoamerican civilization.Science, New Series. 143: 531537.

Méndez, F. 1993. Determination of the area fucked in plants of sugar cane variety c 32368. Caña de Azúcar. 11(2): 33-39.
Morales-Ruiz, A., Morales-Rosales, EJ., FrancoMora, O., Mariezcurrena, BD., Estrada, CG., Norman, MTH. 2014.Population density in maize, light attenuation coefficient and yield. Revista Mexicana de Ciencias Agrícolas. 8: 1425-1431.

Navarro, G.H., Hernández, F.M., Castillo, G.F. and Pérez, O.A. 2012. Diversity and characterization of creole maize varieties: case study in cultivation systems of guerrero's costa chica, Mexico. AgriculturaSociedad y Desarrollo. 9(2): 149165.

Pérez, C.A.A., Molina, G.J.D. and Martínez, G.A. 2000. Adaptation to temperate climate of a tropical maize variety through stratified visual mass selection. 34(5): Agrociencia: 533-542.

Secretaría de Medio Ambiente y Recursos Naturales. 2013. $1^{\text {a }}$ edición. México, D.F. 336 p.

Segovia, S.V.F. and Alfaro, J. Y. J. 2009.The maize: a strategic crop for food sovereignty of venezuelan people. Agronomía Tropical. 59(3): 237-247.

Robutti, L.J. 2004. Quality and uses of maize.IdiaXXI. 6: 100-104.

Rocadio, R.M., Santacruz, V.A., Córdova, T.L., López, S.H., Castillo, G.F., Lobato, O.R., García, Z.J.J. and Ortega, P.R. 2014. Morphological and agronomic characterization of seven maize races from the highlands of Mexico.RevistaFitotécnia Mexicana. 37(4): 351-361.

Zamudio-González, B., Tadeo-Robledo, M., Espinosa-Calderón, A., Martínez-Rodríguez, J.N., Celis-Euan, D.I., Turrent-Fernández, A and Valdivi-Bernal, R. 2015.Physiological efficiency of NPK and Mg in H-47 and H-50 maize. Revista Mexicana de Ciencias Agrícolas.Vol. 6 Núm. 8: 1807-1818.

\section{How to cite this article:}

Alejandro Morales-Ruíz, Ernesto Díaz-López, Edgar Josanine Vargas-Ramírez, Rodolfo Clemente-Resendíz-Melgar, Erika Teresa Díaz-Oreján and Aurelio Trujillo Álvarez. 2017. Ecophysiological Characterization of Seven Cultivars of Maize (Zea mays L.), in the Valley of Tehucan. Int.J.Curr.Microbiol.App.Sci. 6(2): 1870-1875.

doi: http://dx.doi.org/10.20546/ijcmas.2017.602.211 